\title{
Effect of Working Capital Management on Profitability of Listed Manufacturing Companies in Ghana
}

\author{
Jacob Akomeah*, Siaw Frimpong \\ Department of Finance, University of Cape Coast, Cape Coast, Ghana \\ Email address: \\ jacobakomeah@yahoo.com (J. Akomeah),sfrimpong@ucc.edu.gh (S. Frimpong) \\ ${ }^{*}$ Corresponding author
}

To cite this article:

Jacob Akomeah, Siaw Frimpong. Effect of Working Capital Management on Profitability of Listed Manufacturing Companies in Ghana. International Journal of Finance and Banking Research. Vol. 5, No. 2, 2019, pp. 29-35. doi: 10.11648/j.ijfbr.20190502.13

Received: March 31, 2019; Accepted: May 15, 2019; Published: June 26, 2019

\begin{abstract}
Working capital management plays a vital role in the success of businesses because of its effect on profitability. The purpose of this study is to examine the effect of working capital management on the profitability of listed manufacturing firms in Ghana. The study used secondary data collected from seven (7) manufacturing firms listed on the Ghana Stock Exchange for a period of ten years (2005-2014). The profitability as dependent variable was measured in terms of gross operating profit. The working capital was determined by Accounts Receivables Period, Accounts Payables Period, Inventory Conversion Period and Cash Conversion Cycle are used as independent variables. Moreover, current ratio used as liquidity indicator and firm size as measured by logarithm of sales are used as control variables. Data was analysed using the FixedEffects model of the Panel data regression. The regression results revealed that account receivables period (ARP) and inventory conversion period (ICP) days had a statistically significant negative impact on the profitability whiles account payables period (APP) days had insignificant positive effects on the profitability. The study, on the other hand found out that cash conversion cycle (CCC), current ratio (CR), and firm size (LOS) had a significant positive impact on the profitability. The study recommended that manufacturing firms should adopt efficient and effective ways of managing these components of working capital management.
\end{abstract}

Keywords: Working Capital Management, Profitability, Ghana Stock Exchange, Fixed Effect, Random Effect

\section{Introduction}

Working capital management (WCM) is an important corporate financial decision since it directly affects the profitability of the firm. Working capital management efficiency is vital especially for manufacturing firms, where a major part of assets is composed of current assets especially inventory and trade receivables [1]. In their study [2] on working capital management noted that the objective of working capital management is to maintain an optimal balance between each of the working capital components. Working Capital Management (WCM) is an essential part of financial management and contributes significantly to a firm's wealth creation as it directly influences organizational profitability and liquidity. Working capital is the capital available for conducting the day-to-day operations of the business and consists of current assets and current liabilities.
When a business entity takes the decision regarding its current assets and current liabilities it can be termed as Working Capital Management [3]. Therefore, working capital management is the administration of current assets and current liabilities.

The primary components of working capital management include inventory levels, trade credit (accounts receivables), accounts payables, as well as cash conversion cycle. Cash Conversion Cycle is a popular measure of working capital management that reflects the net time interval between actual cash expenditure on a firm's purchase of productive resources and the ultimate recovery of cash receipts from product sales [4].

This study is motivated by the recent global financial crises which significantly affect the liquidity position and the overall business activities across the world. In Ghana, where credit is either not available or expensive to obtain, there are corporate issues across almost all the manufacturing firms 
that have to do with liquidity problem and consequently their operating performance.

Working capital management has been a major issue especially in developed countries and as a result, in order to explain the relationship between working capital management and profitability, research have been carried out in different parts of the world especially in developed countries. Indeed, a lot of research have been conducted in different countries to show the effects of working capital components on firm's profitability [5-9, 3]. However, since Ghana differs from developed countries in terms of capital markets, economy and infrastructural development coupled with the importance of working capital management calls for research on the effects of working capital management on company's profitability. It is intriguing to note that several research works have already been conducted on working capital management practices but it is limited to SMEs and banks in Ghana [10-12]. However, there are few known evidence-based studies, all covering a period of five years in each study, that have investigated how profitable listed manufacturing firms manage their working capital in Ghana. These include few Ghanaian works [13-16]. The five years period used by the previous researchers have provided a gap for this study to fill by extending the period from five years to ten years as this can affirm or contradict their findings. The question then is does working capital management have effects on profitability of listed manufacturing firms in Ghana? Based on this background, the study was designed to assess the effect of working capital management on the profitability of listed manufacturing firms in Ghana. The study was guided by the following research hypotheses: $\mathrm{H}_{01}$ : There is no significant effect of Accounts Receivables Period on the profitability of listed manufacturing firms in Ghana. $\mathrm{H}_{02}$ : There is no significant effect of Accounts Payable Period on the profitability of listed manufacturing firms in Ghana. $\mathrm{H}_{03}$ : Inventory Conversion Period has no significant effect on the profitability of listed manufacturing firms in Ghana. $\mathrm{H}_{04}$ : Cash conversion cycle has no significant impact on the profitability of listed manufacturing firms in Ghana. This discussion on the importance of working capital management, its various components and their impact on profitability leads to the problem statement which would be analyzed in this study. Moreover, this study would validate some of the findings of previous authors by way of examining the relationship between working capital management and profitability of the sample Ghanaian listed manufacturing firms, thus, adding substance to the existing theory and knowledge developed by previous authors. This study therefore attempts to fill the gap by focusing only on manufacturing firms listed on the Ghana Stock Exchange and contribute to the extant literature by using panel data methodology to investigate how profitable manufacturing firms listed on the Ghana Stock Exchange covering the period from 2005-2014 manage their working capital.

\section{Literature Review}

\subsection{Working Capital Management}

Working capital has been defined as the funds locked up in materials, work in progress, finished goods, receivables, and cash and cash equivalent. Thus, they defined working capital as capital invested in current assets, which are those assets that can be converted into cash within a short period of time and the cash received is again invested into the assets [17].

The objective of Working Capital Management (WCM) is to minimize the Cash Conversion Cycle (CCC) the amount of capital tied up in the firm's current assets. It focuses on controlling account receivables and their collection process, and managing the investment in inventory. Working capital management is vital for all business survival, sustainability and its direct impact on performance. [18]

\subsection{Management of Working Capital Components}

The basic working capital components which should be managed efficiently includes the account receivables or debtors collection period, accounts payables or creditors payment period, inventory management, cash and cash equivalents and the operating cycle of a firm.

\subsubsection{Accounts Receivables Management}

Account receivables are assets representing amounts owed to the firm as a result of the sale of goods or services in the ordinary course of business. Accounts receivables period is the average time taken by credit customers to settle their accounts. It was observed that credit customers who pay late or do not pay at all only aggravate the problem. Thus, it is important for the financial manager or account receivables manager to establish a good policy that controls the advantages of offering credit with the associated costs. The firm should establish its receivables policies after carefully considering both the benefits and costs of different policies. [7]

\subsubsection{Accounts Payables Management}

The accounts or trade payables deferral period is the average time taken by a company to pay its trade payables, i.e. its suppliers [19].

The general guidelines for optimizing the managing of account payables involve the timing of payments. Companies should try prolonging the time of payment as long as possible as they can use the advantage of their suppliers financing their investments until payment has been made.

Another argument for prolonging the time for payment is that the producing companies, for example, need some time to convert their purchased raw material into products they can get sold and get cash in return [20]. The account payables period is computed by dividing account payables by net purchases multiplied by 365 days [3].

\subsubsection{Inventory Management}

Inventory turnover in days is another important component of working capital management which is also called as 
inventory conversion period [3]. According to them it is the average time required to convert materials into finished goods and then to sell those goods. This variable helps in evaluating the efficiency in inventory management policy of the firm. If firms take more time in selling inventory which means that inventories are not getting converted into sales, will inevitably decrease the profitability of firm. Inventory Turnover in Days is calculated using inventory divided by the cost of sales multiplied by 365 days.

\subsubsection{Cash Conversion Cycle}

The cash conversion cycle is used in measuring cash management, and it represents the interaction between the components of working capital and the flow of cash within a company [21]. Thus, Cash Conversion Cycle is the duration of time that cash is tied up in accounts receivables and inventory. In fact, the Cash Conversion Cycle (CCC) is concerned with the amount of time a firm's resources are tied up.

It was noted that the longer the cash conversion cycle, the greater the amount of investment required in working capital. The length of the cash conversion cycle depends on the length of: the inventory conversion period; the trade receivables collection period; and the trade payables deferral period. [19]. The length of the cash conversion cycle (CCC) is given by:

$$
\begin{gathered}
\mathrm{CCC}=\text { Inventory days }+ \text { Trade receivables days }- \text { Trade } \\
\text { payables days }
\end{gathered}
$$

\subsection{Theoretical Framework}

According to the agency theory, managers as agents are expected to monitor corporate affairs in a most profitable manner so as to maximize the value of the owners as principals and protect the interest of other stakeholders. Under the theory, managers are responsible for managing the business profitably. One of the factors responsible for the agency problem in the corporate world by the managers is the self-serving interest and incentives. For instance, the interest of the managements usually conflict with the interest of the owners, in which the managers try to meet their goals at the expense of the firm, and this affect the performance in many ways.

In essence, the theory of working capital management describes how working capital should be managed and demonstrates the benefits in terms of liquidity, solvency, efficiency, profitability, and shareholder wealth maximization which accrue to the company from appropriately managing working capital. To satisfy the requirement of efficiency, working capital management seeks to ensure that the investment in working capital components is neither too little nor too great. [18]

The theory provides a framework and a logical linkage between the management of working capital and profitability. Therefore, this study examined the impact of the working capital management and profitability of listed manufacturing firms in Ghana.

\section{Methodology}

\subsection{Research Design and Data Collection}

The researcher used quantitative approach to investigate the effect of working capital management on the profitability of manufacturing firms using a panel data. The study covered the period from 2005 to 2014. Data from seven (7) companies of different sub sectors of the manufacturing and processing industries were used. Data collection can be primary or secondary. This study has used secondary data. Audited financial statements of the selected companies were retrieved from the Ghana Stock Exchange (GSE) website. Where the financial statements of a particular period for a selected company were not available at the Ghana Stock Exchange (GSE) website, they were retrieved from the websites of that particular company. The data is used in computing account receivable period, account payable period, inventory conversion period and other variables.

\subsection{Study Population}

The population for the study consists of manufacturing firms in Ghana. The manufacturing companies on the Ghana Stock Exchange (GSE) were used because of the ease of access to data. In all seven (7) companies were selected from the following manufacturing and processing subsectors, namely: Agro processing, Pharmaceuticals, Aluminum and iron fabrication, Food and Beverages, Household consumables, Paper and Printing and Wood processing industries.

\subsection{Data Processing and Analysis}

The data collected was analyzed statistically and qualitatively by the use of measures of central tendency, that is, the mean, median, maximum, minimum and measures of dispersion, that is, the standard. The variables were verified for stationarity by subjecting them to panel unit root test. In this study, relevant tests were carried out alongside other regression models (Fixed Effects and Random Effects models), to confirm the reliability or otherwise of the OLS in this study. Hausman test was carried out to determine which of the regression models (Fixed Effects and Random Effects) was appropriate. Multicollinearity test was carried out to observe whether the explanatory variables were highly correlated or not. The data was subjected to computerized analysis using E- Views version 9.

\subsection{Control Variables}

\subsubsection{Liquidity (CR)}

The companies with more liquidity have more profitability, so liquidity variable was used as control variable in order to make its effect on profitability neutral. Current ratio was used as liquidity criterion.

\subsubsection{Size of Firm (LOS)}

The companies which have more sales naturally have more profitability too. So the company size was used as a control variable to control this effect. The company size was taken as natural logarithm Net Sales. 


\subsection{Model Specification}

The model uses Gross operating profit (GOP) as dependent variable and four independent variables, which include Account Receivable Period (ARP), Account Payable Period (APP), Inventory Conversion Period (ICP), and Cash Conversion Cycle (CCC), and two control variables which include Current Ratio (CR) and Size of Firm (LOS). To examine the effects of Working Capital Management (WCM) practices on profitability of listed manufacturing firms in Ghana, the model used by [21] has been adopted. Generally, this model is specified as:

$$
\text { Qit }=\alpha+X i t \beta+\varepsilon i t
$$

Where,

$$
\text { Qit }=\text { Profitability }(\mathrm{GOP})
$$

$\alpha=$ the intercept

$\beta=$ coefficient of independent variables

$\mathrm{Xit}=$ independent variables of firm $\mathrm{i}$ at time $\mathrm{t}$

$\varepsilon i t=$ error term of firm $i$ at time $t$

Specifically, the relationship between WCM practices and profitability of listed manufacturing firms in Ghana was modelled using the Ordinary Least Square (OLS) regression technique.

$$
\text { GOPit }=\beta 0+\beta 1 \mathrm{ARPit}+\beta 2 \mathrm{APPit}+\beta 3 \mathrm{ICPit}+\beta 4 \mathrm{CCCit}+\beta 5 \mathrm{CRit}+\beta 6 \mathrm{LOSit}+\varepsilon i \mathrm{t}
$$

Where:

GOPit $=$ Gross Operating Profit of firm $i$ in year $t$.

ARPit $=$ Account Receivable of firm $i$ in year $t$

APPit $=$ Account Payable of firm $i$ in year $t$

ICPit $=$ Inventory Conversion of firm $\mathrm{i}$ in year $\mathrm{t}$

$\mathrm{CCCit}=\mathrm{Cash}$ Conversion Cycle of firm $\mathrm{i}$ in year $\mathrm{t}$
CRit $=$ Current Ratio of firm $\mathrm{i}$ in year $\mathrm{t}$

LOSit $=$ Size of firm $i$ in year $t$

$\varepsilon i t=$ Error term of firm $i$ in year $t$

$\beta 0=$ the intercept

$\beta 1-\beta 4=$ Coefficient of Independent Variables

B5- $\beta 6=$ Coefficients of Control Variable.

Table 1. Presents the Measurement of the Variables in the Study.

\begin{tabular}{ll}
\hline Variables & Measurement \\
\hline Dependent Variable & \\
\hline Gross Operating Profit (GOP) & (Sales-Cost of Goods Sold) (Total Assets-Fixed Financial Assets) \\
Independent Variables & Account Receivables $\times 365$ Sales \\
Accounts Receivables Period (ARP) & Account Payables $\times 365$ Cost of Goods Sold \\
Accounts Payables Period (APP) & Inventory $\times 365$ Cost of Goods Sold \\
Inventory Conversion Period (ICP) & ARP+ICP-APP \\
Cash Conversion Cycle (CCC) & \\
Control Variables & Current Assets/ Current Liabilities \\
Current Ratio (CR) & Natural Logarithm of Sales \\
Size of Firm (LOS) & \\
\hline
\end{tabular}

\section{Results and Discussion}

\subsection{Stationarity Tests}

Panel unit root test

The variables were verified for stationarity by subjecting them to panel unit root test using Levin, Lin \& Chu, Im, Pesaran and Shin W-stat, ADF - Fisher Chi-square and PP Fisher Chi-square test for stationary test. The variables namely Gross Operating Profit (GOP), Accounts Receivable Period (ARP), Accounts payables Period (APP), Inventory Collection Period (ICP), Cash Conversion Cycle (CCC), Current Ration (CR) and Size of Firm (LOS) were stationary at levels. For a variable to be accepted at stationary, more than $50 \%$ of the method (Levin, Lin \& Chu, Im Pesaran and Shin W-stat, ADF-Fisher Chi-square and PP-Fisher Chisquare) must confirm that it is stationary.

Table 2. Results of the Panel Unit Root test for the Dependent, Independent and Control Variables.

\begin{tabular}{llllllll}
\hline Methd & Probability & & & & & \\
\hline & GOP & ARP & APP & ICP & CCC & CR & LOS \\
\hline Levin, Lin \& Chu t* & 0.0001 & 0.0000 & 0.0000 & 0.0005 & 0.0000 & 0.0000 & 0.0000 \\
Im, Pesaran and Shin W-stat & 0.0147 & 0.0065 & 0.0037 & 0.0539 & 0.0049 & 0.0235 & 0.0093 \\
ADF - Fisher Chi-square & 0.0097 & 0.0059 & 0.0061 & 0.0414 & 0.0040 & 0.0123 & 0.0052 \\
PP - Fisher Chi-square & 0.0010 & 0.0027 & 0.0001 & 0.0000 & 0.0460 & 0.0000 & 0.0211 \\
\hline
\end{tabular}

All the four methods in Table 2, suggest that GOP, ARP, APP, CCC, CR and LOS were stationary at levels. Three of the four methods in Table 2, representing $(75 \%)$ also suggest that ICP was stationary at levels.

\subsection{Descriptive Statistics}

Table 3 shows the descriptive statistics of the variables used in the study. It embodies number of observations, minimum, maximum, mean and standard deviation of the variables used.

According to Table 3 average gross operating profit (GOP) is $44.7 \%$ with a maximum of $87 \%$ and a minimum of $9 \%$. The standard deviation is $13.7 \%$, suggesting a wide variation in gross operating profit across the listed manufacturing firms 
in Ghana over the period under investigation.

Account receivables period (ARP) has overall mean of 54 days with a maximum of 139 days, a minimum of 7 days and a standard deviation of 36 days. This means that on average listed manufacturing firms in Ghana do not extend credit to their customers beyond 54 days. Also, the average time taken for the firms to pay their suppliers or creditors that is account payables period (APP) is 81 days, with a maximum of 191 days, a minimum of 2 days and a standard deviation of 47 days. Furthermore, it also takes on average 77 days for listed manufacturing firms in Ghana within the period under investigation to hold inventory or stocks, with a maximum of 229 days, minimum of 11 days and a standard deviation of 42 days.

Table 3 also indicates that on average, it takes 48 days for listed manufacturing firms in Ghana within the period under consideration to convert their input resources (CCC) into cash. However, some of the firms could take as long as 173 days and a minimum of -124 days to achieve this.

Current ratio (CR) has overall mean of 1.3 with a maximum of 2.2 and minimum of 0.4 . This implies that on average the firms always keep enough current assets to offset their current liabilities. The firm size (LOS) has a mean of 6.2 with maximum of 9.1 and minimum of 3.9 with its standard deviation of 0.45 .

Table 3. Descriptive Statistics of the Dependent, Independent, and Control Variables.

\begin{tabular}{|c|c|c|c|c|c|c|c|}
\hline & GOP & ARP & APP & ICP & $\mathrm{CCC}$ & CR & LOS \\
\hline Mean & 0.446857 & 53.78571 & 80.85714 & 76.71429 & 48.18571 & 1.279429 & 6.190286 \\
\hline Median & 0.430000 & 46.00000 & 71.50000 & 72.00000 & 53.00000 & 1.135000 & 5.875000 \\
\hline Maximum & 0.870000 & 139.0000 & 191.0000 & 229.0000 & 173.0000 & 2.200000 & 9.050000 \\
\hline Minimum & 0.090000 & 7.000000 & 2.000000 & 11.00000 & -124.0000 & 0.380000 & 3.890000 \\
\hline Std. Dev. & 0.137341 & 35.88787 & 46.86746 & 41.69529 & 54.31798 & 0.421701 & 1.277125 \\
\hline Skewness & 0.609536 & 0.818564 & 0.422939 & 1.391884 & -0.413477 & 0.254433 & 0.448579 \\
\hline Kurtosis & 4.037772 & 2.705686 & 2.750243 & 5.348155 & 3.374817 & 2.009823 & 2.157822 \\
\hline
\end{tabular}

Fixed- effects model

The fixed-effects model results are displayed below in table 4 .

Table 4. Fixed-Effects Model.

\begin{tabular}{lllll}
\hline Variable & Coefficient & Std. Error & t-Statistic & Prob. \\
\hline C & 0.395845 & 0.192824 & 2.052881 & 0.0447 \\
ARP & -0.005877 & 0.002462 & -2.386993 & 0.0203 \\
APP & 0.001021 & 0.001205 & 0.847564 & 0.4002 \\
ICP & -0.002000 & 0.000845 & -2.367597 & 0.0210 \\
CCC & 0.195667 & 0.027476 & 7.121385 & 0.0000 \\
CR & 0.093920 & 0.040581 & 2.314378 & 0.0243 \\
LOS & 0.102656 & 0.035659 & 2.878838 & 0.0064 \\
\hline
\end{tabular}

Random-effects model

A test was carried using the random-effects. The results are shown below in Table 6 .

Table 5. Random-Effects Model.

\begin{tabular}{lllll}
\hline Variable & Coefficient & Std. Error & t-Statistic & Prob. \\
\hline C & 0.342936 & 0.104245 & 3.289701 & 0.0016 \\
ARP & 0.000409 & 0.001753 & 0.233013 & 0.8165 \\
APP & 0.002370 & 0.000613 & 3.867277 & 0.0003 \\
ICP & -0.002020 & 0.000329 & -6.136754 & 0.0000 \\
CCC & 0.000785 & 0.000281 & 2.798511 & 0.0068 \\
CR & 0.188750 & 0.027225 & 6.932978 & 0.0000 \\
LOS & -0.024713 & 0.011089 & -2.228671 & 0.0294 \\
\hline
\end{tabular}

Correlated Random Effects- Hausman test

Because the individual coefficients of the independent variables are different between the fixed and random effect models, the study attempted to check which model best fits the datasets. In order to determine which of the models is more appropriate to choose, correlated random effectshausman test was carried out. The Hausman test basically tests whether the unique errors are correlated with the regressors. Where they are correlated, preference is made for fixed effect model; otherwise random effect model is selected.

Null hypothesis: Random effects model is appropriate.

Alternative hypothesis: Fixed effects model is appropriate.

Table 6. Hausman Test Results.

\begin{tabular}{llll}
\hline Test Summary & Chi-Sq. Statistic & Chi-Sq. d.f. & Prob. \\
\hline Cross-section random & 109.991363 & 6 & 0.0000 \\
\hline
\end{tabular}

Since the p-value $(0.0000)$ is statistically significant, the null hypothesis (Random-effects model is appropriate) is rejected. This concludes that the fixed-effects model is appropriate. The Hausman test suggests that Fixed Effects Regression model is the most appropriate model for the study as evidenced by the Hausman Chi-sq. statistic of 109.99 with p-value of 0.0000 . The study therefore selects the coefficients of the fixed effect model for further discussions

\subsection{Discussion of Results}

Accounts receivables period (ARP) portray a negative and statistically significant relationship with Gross Operating Profit (GOP). This finding implies that listed manufacturing firms in Ghana will tremendously increase their profitability if they reduce their average collection period. Based on this, the study rejects the null hypothesis one $\left(\mathrm{H}_{01}\right)$ which states that, accounts receivables period has no significant impact on the profitability of listed manufacturing firms in Ghana. This finding is consistent with prior studies including that of $[8$, 11] who stressed the importance of reducing the firm's average collection period in order to enhance profitability.

The study showed that accounts payable period has positive but no significant impact on the profitability of listed manufacturing firms in Ghana, during the period covered by the study. This observation supports [11] who also found no statistically significant association between profitability and average payable days of some selected listed US firms. There 
was a negative relationship between inventory conversion period and profitability of listed manufacturing firms in Ghana. As a result, the study rejects the null hypothesis three $\left(\mathrm{H}_{03}\right)$ which states that inventory collection period has no significant impact on the profitability of listed manufacturing firms in Ghana. This finding implies that listed manufacturing firms in Ghana will increase their profitability if they reduce inventory collection period. This finding, however, is in support of earlier research by [20,7] who found a negative relationship between inventory days and profitability.

Furthermore, there is a positive relationship between cash conversion cycle and profitability of listed manufacturing firms in Ghana. The study rejects the null hypothesis four $\left(\mathrm{H}_{04}\right)$ which states that, cash conversion cycle has no significant impact on the profitability of listed manufacturing firms in Ghana.

Table 7. Summary of Regression Result of the Model of the Study (Dependent Variable).

\begin{tabular}{lllll}
\hline Variable & Coefficient & Std. Error & t-Statistic & Prob \\
\hline C & 0.395845 & 0.192824 & 2.052881 & 0.0447 \\
ARP & -0.005877 & 0.002462 & -2.386993 & 0.0203 \\
APP & 0.001021 & 0.001205 & 0.847564 & 0.4002 \\
ICP & -0.002000 & 0.000845 & -2.367597 & 0.0210 \\
CCC & 0.195667 & 0.027476 & 7.121385 & 0.0000 \\
CR & 0.093920 & 0.040581 & 2.314378 & 0.0243 \\
LOS & 0.102656 & 0.035659 & 2.878838 & 0.0064 \\
R-squared & 0.771681 & & F-statistic & 16.05424 Prob (F-statistic) 0.000000 \\
Adjusted R-squared & 0.723614 & & \\
\hline
\end{tabular}

Again, there is a negative relationship between inventory days (ICP) and the dependent variable, gross operating profit (GOP). This is due to the fact that when inventory days increase by $1 \%$, Gross Operating Profit (GOP) decrease by ($0.002000)$. Therefore, the inventory days with a coefficient of -0.002000 , has statistical significance on profitability.

The regression results also indicate a positive and statistically significant relationship between profitability (GOP) and current ratio (CR) with a coefficient of (0.093920). This means that when current ratio (CR) increases by $1 \%$ profitability (GOP) also increases by 0.093920. This suggests that profitable listed manufacturing firms in Ghana must hold more current assets to enable them repay their current liabilities.

There is a positive and statistically significant relationship between profitability (GOP) and firm size (LOS) with a coefficient of $(0.102656)$. This means that when firm size (LOS) increase by $1 \%$ profitability (GOP) also increase by
0.102656. In support of [7], this finding implies that listed manufacturing firms in Ghana will enhance their profitability if they increase sales.

The adjusted $\mathrm{R}^{2}$ is $(0.772$ or $77.2 \%)$. This indicates that the model is strong fit and shows that $77.2 \%$ of the variation in the dependent variable (GOP) can uniquely or jointly be explained by the independent variables (ARP, APP, ICP, CCC). The remaining $22.8 \%$ can be explained by other factors that are not in the model. The F-statistic (16.05) at pvalue of 0.0000 explains the all over significance of the model. This indicates that there is a significance relationship between the dependent variable (GOP) and all the other independent variables (ARP, APP, ICP CCC).

\subsection{Multicollinearity}

This test was carried to find out whether the explanatory variables are not correlated with one another.

Table 8. Test on Multicollinearity.

\begin{tabular}{lllllll}
\hline & ARP & APP & ICP & CCC & CR \\
\hline ARP & 1.000000 & 0.210916 & 0.136562 & 0.051627 & 0.141030 \\
APP & 0.210916 & 1.000000 & 0.188065 & -0.045318 & 0.090003 \\
ICP & 0.136562 & 0.188065 & 1.000000 & 0.112884 & 0.145399 \\
CCC & 0.051627 & -0.045318 & 0.112884 & 1.000000 & 0.139645 & -0.323689 \\
CR & 0.141030 & 0.090003 & 0.145399 & 0.104919 & 1.000000 & -0.089459 \\
LOS & 0.139645 & -0.323689 & -0.089459 & 0.055167 & -0.076571 & -0.076571 \\
\hline
\end{tabular}

Table 8 shows the results of the multicollinearity test for the explanatory variables used in the study. The explanatory variables are not very highly correlated with each other as the largest observed correlation is 0.21 between the Account Receivables Period (ARP) and Accounts Payables Period (APP) and this is sufficiently small that it can reasonably be ignored.

\section{Conclusion}

This study focuses on the impact of working capital management and profitability of listed manufacturing firms in Ghana. The results and findings from the analysis have implications to policy makers and management of listed manufacturing firms in Ghana. The findings implied that, if policy makers establish proper and effective policies regarding working capital management, profitability could be improved as well as liquidity. This will ensure stable economic condition in Ghana. The findings also implied that more restrictive trade credit policy to customers with less time to make their payments should be instituted by the management of listed 
manufacturing firms in Ghana.

The study has shown a clear understanding of working capital components and how they impact firms' performance. This promotes the efforts of managers to improve their firms' profitability which can be done through appropriate management of working capital components. Thus, management should intensify initiatives to encourage greater understanding and acceptance of working capital components that boost financial performance in listed manufacturing firms in Ghana. In order to boost the wealth of manufacturing firms in Ghana, management should endeavor to find and employ a viable working capital composition that increases firms' financial performance (profitability).

\section{References}

[1] Arunkumar, O. N., \& Ramanan, T. R (2013). Working Capital Management and profitability: A Sensitivity Analysis. International Journal of Research and Development: A Management review, 2, 52-58.

[2] Filbeck, G., \& Krueger, T. (2005). Industry related differences in working capital management. Mid-American Journal of Finance, 20(2), 11-18.

[3] Nasr, M., \& Raheman, A. (2007). Working capital management and Profitability - case of Pakistani firms. International Review of Business Research Papers, 3(1), 279300 .

[4] Laughlin, E. J., \& Richards, V. D. (1980). "Cash conversion cycle approach to liquidity analysis." Financial Management Association International, 9(1), 32-38.

[5] Falope, O. I., \& Ajilore, O. T. (2009). Working capital management and corporate profitability: evidence from panel data analysis of selected quoted companies in Nigeria. Research Journal of Business Management, 3, 73-84.

[6] Lazaridis, I., \& Tryfonidis, D. (2006). Relationship between working capital management and profitability of listed firms in the Athens stock Exchange, Journal of Financial Management, 19. 26-35.

[7] Mansoor, E., \& Muhammad (2012). The Effect of Working Capital Management on Firm's Profitability: Evidence from Singapore. Interdisciplinary Journal of Contemporary Research in Business, 4(5), 472 - 486

[8] Mathuva, D. M. (2010). The Influence of Working Capital Management Components on Corporate Profitability: A Survey on Kenyan Listed Firms. Research Journal of Business Management, 4(1): 1-11.

[9] Stephen, K. K. (2012). Analysis of Effects of Working Capital Management on Profitability of Manufacturing Companies: A Case Study of Listed Manufacturing Companies on Nairobi
Securities Exchange. A Research Project Submitted to the School of Business in Partial Fulfillment of the Requirements for the Award of a Master of Business Administration Degree (Finance Option) of Kabarak University.

[10] Agyei-Mensah, K. (2012). Working Capital Management Practices of Small Firms in the Ashanti Region of Ghana. International Journal of Academic Research in Business and Social Sciences, Vol. 2, No. 1 ISSN: 2222-6990.

[11] Agyei, S. K., \& Yeboah, B. (2011). Working Capital Management and Profitability of Banks in Ghana. British Journal of Economics, Finance and Management Sciences, November 2011, Vol. 2 (2).

[12] Pieterson, A. (2012). Working-capital Management practices of Small and Medium Enterprises in the Western Region: A survey of selected SMEs in the Sekondi-Takoradi Metropolis. Published Dissertation submitted for Masters of Business Administration. Kwame Nkrumah University of Science and Technology.

[13] Akoto, K. R., Awunyo-Victor, D., \& Angmor, P. L. (2013). Working capital management and Profitability: Evidence from Ghanaian listed manufacturing firms. Journal of Economic and International Finance, 5(6), 373-379.

[14] Agyemang Badu, E., \& Asiedu Michael, K. (2013). The Relationship between Working Capital Management and Profitability of Listed Manufacturing Companies in Ghana. International Journal of Business and Social Research (IJBSR), Volume -3, No.-2.

[15] Awuah-Agyeman, D. (2015). Assessing the Impact of Capital Structure on Profitability of Manufacturing Industry in Ghana. Unpublished MBA Thesis, University of Science and Technology

[16] Korankye, T., \& Adarquah, R. S. (2013). Empirical Analysis of Working Capital Management and its impact on the profitability of listed manufacturing firms in Ghana. Research Journal of Finance and Accounting, 4 (1), 124-131.

[17] Khan, M. Y., \& Jain, P. J. (2007). Financial Management. Tax, Problems and Cases. 5th Ed, Tata, McGraw Hill Publishing Company Limited.

[18] Gitman, L. A. (2009). Principles of Managerial Finance, (12th ed)., Pearson Addison Wesley, Boston.

[19] Uyar, A. (2009). The relationship of cash conversion cycle with firm size and profitability: An Empirical investigation in Turkey. International Research Journal of Finance and Economics, 24, 186-193.

[20] Maness, T. S. \& Zietlow, J. T. (2005). Short-Term Financial Management (3rd ed.). Ohio: South-Western/Thomson Learning.

[21] Wang, Y. J. (2002). Liquidity management, operating performance and corporate value: Evidence from Japan and Taiwan. Journal of Multinational Financial Management. 12(2), 159-169. 